Şırnak Üniversitesi

Ilahiyat Fakültesi Dergisi

Sayı 26 Haziran 2021

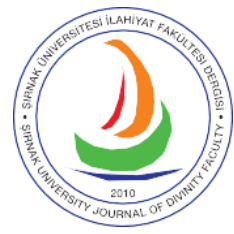

e-ISSN 2667-6575
Şırnak University

Journal of Divinity Faculty

Issue 26 June 2021

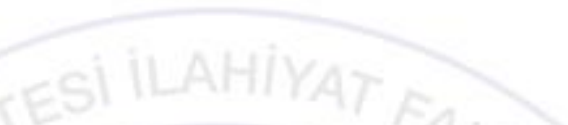

\title{
İslâm Ceza Muhakemesinde Baskı ve Şiddet Yoluyla Elde Edilen İtirafın İspat Değeri
}

Proof Value of Confession Obtained through Pressure and Violence in Islamic Criminal Procedure

\section{Üzeyir KÖSE}

Dr. Öğr. Üyesi, Kilis 7 Aralık Üniversitesi, İlahiyat Fakültesi, İslam Hukuku Ana Bilim Dalı Assistant Professor, Kilis 7 Aralık University, Faculty of Divinity, Department of Islamic Law

Kilis, Turkey

uzeyirkose@kilis.edu.tr

https://orcid.org/0000-0001-6877-4465

\section{Makale Bilgisi / Article Information}

Makale Türü / Article Types: Araştırma Makalesi / Research Article

Geliş Tarihi / Received: 29 Mart / March 2021

Kabul Tarihi / Accepted: 22 Mayıs / May 2021

Yayın Tarihi / Published: 15 Haziran / June 2021

Sayı / Issue: 26 Sayfa / Pages: 381-404

Atıf / Cite as: Köse, Üzeyir. “İslâm Ceza Muhakemesinde Baskı ve Şiddet Yoluyla Elde Edilen İtirafın İspat Değeri [Proof Value of Confession Obtained through Pressure and Violence in Islamic Criminal Procedure]". Şırnak Üniversitesi IIlahiyat Fakültesi Dergisi - Şırnak University Journal of Divinity Faculty 26 (June 2021), 381-404. https://doi.org/10.35415/sirnakifd.904926

Etik Beyanı / Ethics Declaration: Bu makalede bilimsel araştırma ve yayın etiği ilkelerine riayet edilmiştir. Makale etik izin gerektirmeyen bir çalışma olup en az iki hakem tarafından incelenmiş ve intihal içermediği teyit edilmiştir. / In this article, the principles of scientific research and publication ethics are respected. The article is a study that does not require ethical permission. It has been reviewed by at least two referees and was confirmed that it did not contain plagiarism.

Copyright () Published by Şırnak Üniversitesi, İlahiyat Fakültesi / Şırnak, Türkiye (Şırnak University, Faculty of Divinity, Şırnak, 73000 Turkey). 


\section{Özet}

Ceza muhakemesinde temel amaç, hukuka aykırı bir fiilin failinin ortaya çıkarılmasıdır. Diğer bir ifadeyle ceza muhakemesinin amacı deliller vasıtasıyla gerçeğe ulaşmaktır. Ancak İslâm ceza muhakemesinde maddi gerçeği araştırma ve ortaya çıkarma mutlak bir amaç değildir. Özellikle kamu haklarını ihlal eden suçların ifşa edilmesi pek istenmez. Ayrıca sanığa ceza verilebilmesi için suçun şüpheden uzak bir şekilde ispat edilmesi gerekir. Temel ispat vasitalarından biri olan itiraf, kişinin işlemiş olduğu suçu haber vermesi ya da kendisine yöneltilen suçlamayı kabul etmesi demektir. Herhangi bir baskı ve zorlama olmaksızın elde edilen itiraf, ispat vasıtaları arasında ilk sırada yer alır. İsnat edilen suçu itiraf ettirmek ya da maddi delillere ulaşmak maksadıyla sanığa baskı ve şiddet uygulamanın hükmü ve bu şekilde elde edilen itirafın ispat değeri ise fakihler arasında tartışma konusudur. Fakihlerin çoğunluğuna göre daha önce suça karışmamış ve toplumda iyi haliyle bilinen sanığa baskı ve şiddet uygulanması caiz görülmediği gibi bu şekilde elde edilen itiraf da muhakemede delil olarak kullanılamaz. Sanığın adam öldürme, hırsızlık, gasp vb. suçlardan sabıkalı olması ve itham edilen suçu işlemiş olabileceğine dair kuvvetli karinelerin mevcudiyeti durumunda ise bazı fakihler, sanığın baskı ve şiddet yoluyla itirafa zorlanmasını caiz kabul etmişlerdir. Nitekim hırsızlıkla tanınmış bir kimsenin yine aynı suçu işlediği yönünde güçlü karineler bulunmakla birlikte sanığın suçlamayı kabul etmediği durumlarda ikrarda bulunması için hapis ya da baskı araçlarının kullanılabileceği ifade edilmektedir. Bu kanaatte olanların temel gerekçeleri, sanıkların baskı ve şiddet olmaksızın suçu kabullenmemeleridir. Gazzâlî'nin de içinde bulunduğu birtakım fakihler ise daha önce suça karışmış kimselerin önyargıyla suçlu kabul edilip itirafa zorlanmasına karşı çıkmışlardır. Bunlara göre sanığın isnat edilen suçu işleme ihtimali olduğu gibi suçsuz olma ihtimali de vardır. Suçsuz birinin baskı ve şiddete maruz bırakılması yerine suçlunun şiddet görmemesi tercih edilmelidir. İnsanlara haksız yere eziyet edilmesini yasaklayan ayetlerin yanında İslâm'ın insana vermiş olduğu değer bunu gerektirmektedir. Diğer taraftan suç objektif delillerle ispat edilmedikçe, devlet başkanı da olsa, şüphe sebebiyle kimsenin cezalandırma yetkisi olmadığını ifade eden rivayetler bulunmaktadır. İslâm ceza muhakemesinde şahitlik ve ikrar gibi ispat vasıtalarının yanında maddi deliller de kullanılmaktadır. Çalınan malın sanığın yanında ya da evinde bulunması hırsızlık suçunun ispatında; cinayet silahı ise kısas davalarında maddi delil olarak kullanılmaya müsaittir. Fakihlerin genel kanaati, sanığa baskı ve şiddet uygulayarak maddi delil elde etme çabasının caiz olmadığı yönündedir. Bununla birlikte özellikle hırsızlık suçlarında çalınan malın yerini ve varsa suç ortaklarını öğrenmek maksadıyla sanı̆ga baskı yapılabileceğini kabul eden fakihler bulunmaktadır. Baskı ve şiddet sonucu sanık, suçunu itiraf edip çaldığı malı ortaya çıkarırsa suçun aslî cezası uygulanacaktır. Ancak bu ceza baskıyla elde edilen itirafa dayanmayıp, hırsızlığı ortaya koyan maddi delile dayanmaktadır. Osmanlı kanunnamelerinde de benzer anlayışa rastlamak mümkündür. Bazı fakihlerin ve Osmanlı kanunnamelerinin açmış olduğu bu aralık, sonraki dönemlerde genişlemiş ve kimi zaman ilgili konuda sabıkası olmayan kişiler de haksız yere baskı ve işkenceye maruz kalmışlardır. 19. yüzyıldan itibaren ise çeşitli belgelerde işkenceye müsamaha edilmeyeceği hükme bağlanmış, baskı ve şiddet sonucu elde edilmiş itiraflar mahkeme tarafından geçersiz sayılarak suçun tespitinin ve suçluların cezalandırılmasının yasal bir zemine oturtulması anlayışı benimsenmiştir.

Anahtar Kelimeler: İslâm Hukuku, Yargılama, Delil, İtiraf, Baskı ve Şiddet, Ceza. 


\section{Summary}

The main purpose in criminal procedure is to reveal the perpetrator of an illegal act. In other words, the purpose of criminal procedure is to reach the truth through evidence. However, searching and uncovering the material truth is not an absolute goal in the Islamic criminal procedure. Disclosure of crimes that violate civil rights is particularly undesirable. In addition, in order for the accused to be punished, the crime must be proven without suspicion. Confession, which is one of the basic means of proof, means that the person informs the crime he has committed or accepts the accusation against him. Confession obtained without any pressure or coercion takes the first place among the means of proof. The legality of applying pressure and violence to the accused in order to have a confession for the alleged crime or to obtain material evidence and the proof value of the confession obtained in this way are a matter of debate among scholars. According to the majority of jurists, it is not permissible to apply pressure and violence to the accused who has not been involved in crime before and who is well known in the society, and the confession obtained in this way cannot be used as evidence in the proceedings. If the accused has a criminal record for crimes such as murder, theft and extortion, and there is a strong presumption that he/she may have committed the alleged crime, some jurists have accepted it permissible to force the accused to confess through pressure and violence. As a matter of fact, it is stated that imprisonment or pressure can be used as a tool to have a confession in cases where a person known for theft does not accept the accusation even though there are strong presumptions that he/she has committed the same crime. The main grounds of those with this opinion are that the defendants do not admit the crime without pressure and violence. Some jurists, including Ghazali, objected to treat those who had not committed a crime before as guilty with prejudice and force them to confess. According to them, there is the possibility that the accused is guilty as well as not committing the alleged crime. In order not to expose an innocent person to oppression and violence, it should be preferred not to subject someone to violence even if he/she has a criminal record. In addition to the verses prohibiting torture, the value that Islam gives to people necessitates this. On the other hand, there are rumours stating that nobody has the authority to punish due to suspicion unless the crime is proven by objective evidence. In the criminal procedure of Islam, besides the means of proof such as witness and confession, material evidence is also used. If the stolen property is found with the accused or in his/her house, it can be used to prove the crime of theft. The murder weapon, on the other hand, can be used as material evidence in retribution cases. The general opinion of the jurists is that it is not permissible to try to obtain material evidence by applying pressure and violence to the accused. However, there are jurists who accepts that pressure can be used to learn the location of the stolen property and, if any, their accomplices in cases of theft. If the accused confesses the crime with pressure and violence, and reveals the stolen property, the actual punishment of the crime will be applied. However, this punishment is not based on a confession obtained by pressure, but on material evidence revealing the theft. It is possible to find a similar understanding in Ottoman law books. This gap, which was opened by some jurists and Ottoman law books, was expanded in the following periods and sometimes people who did not have a criminal record were exposed to unfair oppression and torture. Since the 19th century, it has been decreed in various documents that torture will not be tolerated, confessions obtained as a result of pressure and violence were declared invalid by the court, and an understanding of establishing a system in which detection of the crime and the punishment of the criminals are put on a legal basis has been adopted.

Keywords: Islamic Law, Judgment, Evidence, Confession, Repression and Violence, Penalty. 


\section{Giriş}

Tarihi süreçte adalet kavramı siyaset, sosyoloji, ahlak ve hukuk gibi birçok disiplinin temel çalışma alanlarından biri olmuştur. Bu sebeple adalet kavramının ve adaleti sağlama idealinin hukuki temellerinin yanı sıra dinî ve ahlaki temelleri de bulunmaktadır. Kısaca hak ve hukukun yerini bulması şeklinde ifade edilebilecek olan adalet, hukukun özü ve nihai hedefidir. Vatandaşlarının haklarını koruma vazifesini üzerine alan devlet, adaleti tesis etmekle mükelleftir. ${ }^{1}$ İslâm muhakeme hukukunda adaletle hüküm "hak ile hüküm” şeklinde anlaşılmıştır. Hz. Peygamber ve raşit halifeler, bu sorumluluğu daha çok kendileri üstlenmiştir. İlerleyen süreçte ise bu yetki/sorumluluk hâkimlerle paylaşılmıştır. Hâkimlik müessesesinin temel görevi gerek ceza davalarında gerekse medenî hukuk davalarında hakkaniyet çerçevesinde hükümler vermektir. Hatta adil yargılamanın sağlanması, yöneticilerin öncelikli vazifelerinden sayılmıştır. ${ }^{2}$ Bu kabulde Kur'an'ın çeşitli vesilelerle adalete yapmış olduğu vurgunun ${ }^{3}$ etkili olduğu söylenebilir. Diğer taraftan adaletten ayrılmama düşüncesi, muhakemede objektif kriterleri esas alma anlayışını doğurmuştur. Bunun bir sonucu olarak da klasik İslâm hukukçularının çoğunluğu, muhakemede hâkimlere takdir yetkisi verilmesini doğru bulmamışlardır. Diğer bir ifadeyle hâkimler, davalarda belirli ispat vasıtalarını kullanmakla sınırlandırılmıştır. ${ }^{4}$ İspat vasıtaları genel olarak şahitlik, ikrar, yemin, nükûl, kasâme, hâkimin şahsi bilgisi ve kuvvetli karine şeklinde sıralanmaktadır. Ancak bu ispat vasıtalarından şahitlik ve ikrar dışındakiler fakihler arasında tartışmalıdır. ${ }^{5}$

İbn Teymiyye (öl. 728/1328), İbn Kayyim (öl. 751/1350) ve İbn Ferhûn (öl. 799/1397) gibi fakihler ise ispat vasıtalarının sınırlandırılmasına karşı çıkmışlardır. ${ }^{6} \mathrm{Bu}$ ihtilaf, beyyinenin

1 Mahmut Şen, “İslam Hukuk Geleneği Perspektifinden Yargı Etik İlkeleri”, Uyuşmazlık Mahkemesi Dergisi 6 (Ocak 2006), 506.

2 Şeyhü'l-İ̀slâm Takiyyüddîn Ahmed b. ‘Abdi'l-Halîm İbn Teymiyye, es-Siyâsetü'ş-şer'iyye (Riyad: Vizâratü'şŞuûni'l-İslâmiyye, 1419/1999), 51; Burhânüddîn Ebi'l-Vefâ İbrâhîm b. Şemsüddîn Ebî 'Abdillâh Muhammed b. Ferhûn, Tabṣıratü'l-ḥükkâm fî uṣ̂̂li'l-akḍiye ve menâhici'l-Aḥkâm (Riyad: Dârü 'Alemi'l-Kütüb, 1423/2003), 1/10-12; Nasi Aslan, "Kur'ân ve Sünnete Göre Sanık ve Mahkûm Hakları", Kur'ân ve Sünnete Göre Temel İnsan Hakları, ed. Muhsin Demirci (İstanbul: Ensar Neşriyat, 2014), 531-533.

3 en-Nisâ 4/58; el-Mâide 5/8; en-Nahl 16/90; eş-Şûrâ 42/15.

4 Vehbe Zuhaylî, Vesâilü'l-isbât fi'ş-şerî'ati'l-İslâmiyye fi'l-muâmelâti'l-medeniyye ve'l-ahvoâli'ş-şahșiyye, (Şam-Beyrut: Mektebetü Dâri'l-Beyân, 1402/1982), 605; Ahmed İbrâhîm Bek-Vâṣıl 'Alâuddîn Ahmed İbrâhîm, Ṭuruku'lisbâti'ş-şer 'iyye (Kahire: Mektebetü'l-Ezheriyye li't-Türâs, 2003), 41; Adnan Koşum, İslam Hukuk Doktrininde Yargı Hataları (Isparta: Fakülte Kitabevi, 2004), 65.

5 Zuhaylî, Vesâilü'l-isbât, 606.

6 İmâm Ebî 'Abdillâh Muhammed b. Ebî Bekr b. Eyyûb İbn Kayyim el-Cevziyye, eț-Turuku'l-hukmiyye fi'ssiyâseti'ş-şer'iyye, thk. Nâyif b. Aḥmed el-Ḥamed (Mekke: Dârü 'Alemi'l-Fevâid, 1428), 1/25; Zuhaylî, Vesâilü'lisbât, 609 . 
mahiyeti noktasındaki görüş ayrılığından kaynaklanmaktadır. Cumhura göre beyyine, şahitlikten ibarettir. Zira birçok âyette temel ispat vasıtası olarak şahitlik zikredilmektedir.7 İbn Teymiyye ve İbn Ḳayyim'in öncülük ettiği bazı fakihlere göre ise hakkı ortaya çıkaran her delil beyyinedir. Bu kanaatte olanlar, delilin naslarda zikredilip edilmemesi arasında da ayrım yapmamışlardır.8 İbn Kayyim'e göre beyyine kavramının Kur'an ve sünnetteki kullanımına bakıldığında bununla hakkı beyan eden, hakkı ortaya çıkaran her türlü delilin kastedildiği görülmektedir. Bunun delilsiz olarak bir, iki ya da dört şahitle sınırlandırılması, kavrama tam anlamını vermemek olacaktır. Kur'an' da ister tekil ister çoğul halde kullanılmış olsun beyyine kavramıyla kastedilen mananın hüccet, delil ve burhân olduğu görülmektedir. Ona göre beyyine getirmenin davacıya ait olduğunu ifade eden hadiste de davacının iddiasının doğruluğunu ortaya koyacak her türlü delil kastedilmektedir. ${ }^{9}$

İslâm muhakeme hukuku alanında telif edilen modern çalışmalarda beyyine kavramının kapsamı ve Hz. Peygamber'in kâif, kur'a, karine vb. ispat vasıtalarına dayanarak verdiği hükümler dikkate alınarak ikinci görüşün tercihe şayan olduğu ifade edilmektedir. Diğer taraftan fotoğraf, video, ses kayıtları, parmak izi gibi modern teknolojinin sunmuş olduğu imkânları göz ardı ederek naslarda zikredilen ispat vasıtalarıyla yetinmek, adaletten uzaklaşmaya ve muhakeme usulünde çağın gerisinde kalmaya sebebiyet verebilecektir. ${ }^{10}$ Bununla birlikte ispat vasıtalarını tamamen hâkimin takdirine bırakmak da bazen istenmeyen neticeler doğurabilir. Sanığın baskı ve şiddet yoluyla itirafa zorlanması ya da bu yolla maddi delillere ulaşılmak istenmesi bunlar arasındadır. Modern hukukta bu şekilde elde edilen delillerin ispat değeri üzerine çeşitli çalışmalar yapılmıştır. ${ }^{11}$ Araştırmalarımız neticesinde İslâm ceza muhakemesi alanında doğrudan bu konuda yapılmış bir çalışmaya rastlamış değiliz. Ancak bazı çalışmalarda bu konuya temas edildiği görülmektedir. Cevat Akşit'in İslâm

7 el-Bakara 2/282; el-Mâ'ide 5/106; en-Nûr 24/4; et-Talâk 65/2.

8 'Ârif 'Ali 'Ârif el-Ḳaradâĝ̀, Mesâilü fikhiyye mu'ạștra (Malezya: IIUM Press-International Islamic University Malaysia, 1432/2011), 20-21; Bek-İbrâhîm, Țuruku'l-isbâti'ş-şer 'iyye, 37-38; Saî̂d b. Dervîş ez-Zehrânî, Tarâiku'lhukm fi'ş-şerîati'l-İslâmiyye (Cidde: Mektebetü'ṣ-Ṣahâbe, 1414/1994), 17-18.

9 İbn Kayyim, eț-Ṭuruku'l-ḥukmiyye, 25-26.

10 ez-Zehrânî, Țarâiku'l-ḥukm, 29-30; Şevket Pekdemir, İslam Ceza Hukukuna Göre Adli Tıp ve Maddi Delil (Ankara: Nobel Bilimsel Eserler, 2018), 149-151, 153.

11 Fatih Özkul, "Ceza Yargılamasında Hukuka Aykırı Şekilde Elde Edilen Delillerin Değerlendirilmesi Sorunu”, Uyuşmazlık Mahkemesi Dergisi 0/9 (Haziran 2017), 397-425; Cem Şenol, Ceza Muhakemesi Hukukunda Hukuka Aykırı Delillerin Değerlendirilmesi Yasağı (İstanbul: Marmara Üniversitesi, Sosyal Bilimler Enstitüsü, Doktora Tezi, 2015), 202-209. 
Ceza Hukuku ve İnsani Esasları ve Esra Çetinkaya'nın İslam Hukuku'nda Hukuka Aykırı Yollarla Elde Edilen Delillerin İspat Hukukundaki Değeri adlı çalışmaları bunlar arasında zikredilebilir.

\section{Genel Olarak İslâm Ceza Muhakemesinin Amacı}

Modern hukuk sistemlerinde ceza muhakemesinin amacı, hukuka aykırı bir fiilin failinin ortaya çıkarılması olarak belirlenmiştir. Diğer bir ifadeyle ceza muhakemesinin amacı maddi gerçeğin ortaya çıkarılmasıdır. ${ }^{12}$ Ancak bu, ceza muhakemesinin nihai hedefi değildir. Ceza muhakemesinin bir başka amacı, toplumsal barışı ve düzeni korumaktır. Bunun için ceza muhakemesi suçluların hak ettikleri şekilde cezalandırılmasını, suçsuzların herhangi bir şekilde cezalandırılmamasını, zanlıların ise ancak zaruret ölçüsünde temel hak ve özgürlüklerinden mahrum edilmelerini amaçlamaktadır. ${ }^{13}$

Buradan hareketle modern ceza muhakemesi hukukunun birden fazla amacı bir arada gerçekleştirme gayesi güttüğü söylenebilir. İslâm ceza muhakemesinin de benzer amaçlar taşıdığg görülmektedir. Hz. Peygamber'in -özellikle geri dönüşü olmayan had cezalarındahükmün kesin delillere dayanmasının gereğine yaptığı vurgu ve "hâkimin affetmede hata etmesinin cezalandırmada hata etmesinden evlâ olduğunu" ifade eden sözleri14, ceza muhakemesinde maddi hakikate ulaşmanın ve bununla hüküm vermenin amaçlandığına işaret etmektedir. ${ }^{15}$ Bununla birlikte İslâm ceza muhakemesinde maddi gerçeği araştırma ve ortaya çıkarma mutlak bir amaç olarak anlaşılmamalıdır. İslâm hukukunun hadler ve diğer suçlar arasında yapmış olduğu ayrımda bu durum açıkça görülmektedir. Bu ayrıma göre Allah hakkını ihlâl eden fiillerin mutlak surette cezalandırılması bir amaç değildir. Şayet suç aleniyet kazanmamışsa suçun ortaya çıkması istenmez. ${ }^{16} \mathrm{Bu}$ durumda suçtan ziyade bir günahtan bahsedilir ve bunun hesabı da Allah ile kul arasındadır.

12 Mehmet Akman, Osmanl Devleti'nde Ceza Yargılaması (İstanbul: Eren Yayıncılık, 2004), 19; Özkul, “Ceza Yargılamasında Hukuka Aykırı Şekilde Elde Edilen Delillerin Değerlendirilmesi Sorunu", 400; Şenol, Ceza Muhakemesi Hukukunda Hukuka Aykırı Delillerin Değerlendirilmesi Yasağı, 6-7.

13 Sahip Beroje, Ceza Muhâkemesi Hukuku Açısından İslâm İspat Hukuku, (Ankara: Fecr Yayınları, 2007), 110.

14 Ebû 'Îsâ Muhammed b. 'Îsâ b. Sevre Tirmizî, el-Câmi 'u'ṣ- șahîhh, (Beyrut: Dârü'l-Ḡarbi'l-İslâmî, 1998), "Hudûd" 2; Ebî Bekr Aḥmed b. Ḥuseyn b. Alî Beyhakî, es-Sünenü'l-kübrâ, thk. Muhammed Abdülḳâdir Ațâ, (Beyrut: Dârü'l-kütübi'l-ilmiyye, 1424/2003), 8/413-414.

15 Şemsü'l-Eimme Ebû Bekr Muhammed b. Ebî Sehl es-Serahsî̀, el-Mebsût (Beyrût: Dârü'l-Mârife, 1989), 9/106.

16 Muhammed Ebû Zehrâ, el-Cerîme ve'l-'ukûbe fi'l-fikhi'l-İslâmî: el- 'Ukûbe. (Kahire: Dârü'l-Fikri'l-'Arabî, ts.), 178; Sabri Erturhan, "Kişisel Boyutlu Suçların Gizlenmesinin İslâm Ceza Hukuku Açısından Değerlendirilmesi", Cumhuriyet Üniversitesi Illâhiyat Fakültesi Dergisi 5/2 (2001), 261-278; Beroje, İslâm İspat Hukuku, 141-142, 154-156. 
İslâm muhakeme hukukunda asıl olan iddia sahibinin iddiasını ispatlamakla, savunma makamında olan tarafın da yeminle mükellef olmasıdır. ${ }^{17} \mathrm{Bu}$ ilkenin dayanağı $\mathrm{Hz}$. Peygamber'in "beyyinenin davacıya, yeminin ise davalıya" ait olduğunu ifade eden hadisidir. ${ }^{18}$ Davacı konumundaki iddia sahibi, çoğu zaman mevcut durumun aksini iddia etmektedir. Bu sebeple ondan iddiasını ispat edecek kuvvetli delil ya da deliller getirmesi istenir. Davalıdan ise yemin etmesi istenir. İddia sahibinin, iddiasını ispat edecek deliller ikame edememesi durumunda davalının aklanması için yeminin yeterli görülmesi hem muhakeme hukukunun ilkeleriyle hem de "berâat-i zimmet asıldır" ilkesiyle açıklanabilir.19 Bu usul daha çok hukuk davalarında takip edilmektedir. İslâm ceza muhakemesinde ise sürecin her zaman bu şekilde işlediğini söylemek mümkün değildir. Bazı davalarda adil bir yargılama ve isabetli hüküm için delillerin toplanması ve değerlendirilmesi hâkimin ve yardımcı mahkeme görevlilerinin sorumluluğu olarak kabul edilmektedir. ${ }^{20}$ Diğer taraftan İslâm hukukunda ceza davalarında kullanılan ispat vasıtaları ile ilgili şartlar daha sıkı tutulmuştur. Zira hukuk davalarında aksi ispatlandığında haksız yere verilmiş bir hükmün telafi edilme imkânı mevcuttur. Ceza davalarında ise bu durum çoğunlukla mümkün olmamaktadır. ${ }^{21}$ Muhakeme neticesinde zanlının hukuka aykırı fiilin fâili olduğu ispatlanamamışsa, diğer bir ifadeyle şüphe varsa bu şüphe sanık lehine yorumlanacak ve sanığın mahkûmiyetine hükmedilemeyecektir. Bu sebeple hâkim, ceza davalarında kesin

17 Serahsî, el-Mebsût, 17/28-29; İmâm 'Alâuddîn Ebî Bekr b. Mes'ûd Kâsânî, Bedâi 'u's-sanâi i fî tertîbî'ş-şerâi 'i (Beyrut: Dârü'l-Kütübi'l-'Arabî, 1394/1974), 6/225; Muvaffaḳuddîn Ebî Muhammed Abdullâh b. Ahmed b. Muhammed İbn Kudâme, el-Mug்n̂̀, thk: Abdullâh b. Abdulmuḥsin et-Türkî, 3. Baskı (Riyad: Dârü 'Alemi'lKütüb, 1417/1997), 14/123; İbn Kayyim, eț-Ṭuruku'l-ḥukmiyye, 246-247; Burhânüddîn Ebi'l-Vefâ İbrâhîm b. Şemsüddîn Ebî 'Abdillâh Muhammed İbn Ferhûn, Tabṣıtratü'l-hükkâm fî uṣ̂uli'l-akḍiye ve menâhici'l-Ahkâm. (Riyad: Dârü 'Alemi'l-Kütüb, 1423/2003), 1/105.

18 Ebû Abdillah Muhammed b. İsmâ 'îl Buhârî, el-Câmi 'u's-șahîh (İstanbul: Çağrı Yayınları, 1992), “Rehn”, 6; Ebu'1Huseyn Müslim b. el-Haccâc el-Kuşeyrî en-Nisâburî Müslim, el-Câmi 'u's-ṣahîh, (İstanbul: Çağrı Yayınları, 1981), "Akdiyye", 1.

19 Ḳâsânî, Bedâi 'u's-sanâi 'i, 6/225; Zuhaylî, Vesâilü'l-isbât, 632-633; Ali Bardakoğlu, "İsbat", Türkiye Diyanet Vakfı İslâm Ansiklopedisi (İstanbul: TDV Yayınları, 2000), 22: 493; Aslan, “Sanık ve Mahkûm Hakları”, 534-535.

20 Ebi'l-Hasen 'Ali b. Muhammed b. Habîb el-Mâverdî, el-Ahkâmü's-sultâniyye ve'l-velâyâti'd-dîniyye, thk. Kâdîi Nebîl 'Abdurraḥmân Hayyâvî (Beyrut: Dârü'l-Erḳâm, ts.), 297-298; Tâhâ C. 'Alvânî, "İslâm'da Sanık Hakları (I)”, çev. F. Mehveş Kayani, İslâmî Sosyal Bilimler Dergisi 3/1 (Bahar 1415/1995), 91; Beroje, İslâm İspat Hukuku, 145; Abdulaziz Bayındır, İslâm Muhâkeme Hukûku (İstanbul: Süleymaniye Vakfı Yayınları, 1437/2015), 153-154; Kemal Yıldız, İslâm Yargılama Hukukunda Şahitlik (İstanbul: Hâcegân Akademi Kitaplı̆̆ı, 2005), 23.

21 Fahrettin Atar, İslâm Yargılama Hukukunun Esasları (İstanbul: Marmara Üniversitesi İlahiyat Fakültesi Vakfı Yayınları, 2017), 51. 
delillerle hüküm vermek zorundadır. ${ }^{22}$ Delillere ulaşma ve ulaşılan delilleri kullanma noktasında hâkimin yetki ve sorumluluğunun sınırları ise tartışma konusudur.

\section{Baskı ve Şiddet Yoluyla Elde Edilen Deliller}

Baskı ve şiddet sonucu elde edilen delillerin muhakeme hukukundaki ispat değeri tartışmalıdır. Modern hukukta bu şekilde elde edilen deliller, genel olarak, hukuka aykırı delil olarak nitelenmektedir. Bu sebeple öncelikle hukuka aykırılık kavramı üzerinde durmamız faydalı olacaktır. Hukuka aykırılık, modern hukukta fiil ile hukuk sistemi arasındaki çatışmayı, diğer bir deyişle fiilin hukuk düzenine uygun olmayışını ifade etmektedir. ${ }^{23}$ Bir fiilin hukuka aykırı kabul edilmesi, yazılı ya da yazılı olmayan birtakım kuralları ihlal etmesiyle doğrudan ilgilidir. Fıkıh kaynaklarında hukuka aykırılığg ifade etmek için "cinâyet", "te’addî” ve "bi gayr-i hakk" gibi çeşitli ifadeler yer almaktadır. Kullanıldığı yere göre farklı anlamlar taşımakla birlikte bunların ortak özelliği hukuka aykırılığı, sınırı aşmayı, yetkisiz harekette bulunmayı ifade etmeleridir. ${ }^{24}$ Örneğin "te'addî” kavramı haksız yere, düşmanca davranış, haddi aşmak, başkalarının hakkına tecavüzde bulunmak, zulüm ${ }^{25} \mathrm{vb}$. anlamlar ifade etmektedir. Aynı kökten gelen "i'tedâ" ve türevleri²6 de Kur'an'da benzer anlamlarda kullanilmaktadır.

İslâm hukukunda hukuka aykırılık; yasak bir fiil ile nasların himaye ettiği değerleri ihlal eden davranışları kapsamaktadır. Modern hukukta ise hukuka aykırılık, uyuşmazlığa konu olan fiilin hukuk düzeni tarafından tanınmaması, hukukun koruma altına aldığı hak ve menfaatlere aykırı olmasıdır. Bir fiilin hukuka aykırı olması sadece ceza hukukuna aykırı olması anlamına gelmeyip fiilin tüm hukuk sistemine aykırı olması demektir. Ceza muhakemesinde hukuka aykırılığın sınırlarını net bir şekilde ortaya koyabilmek oldukça güçtür. Mahkemeye sunulan delillerin ispat değerinin belirlenmesi muhakemenin seyri açısından oldukça önem taşımaktadır. ${ }^{27}$ Modern hukuk doktrininde hukuka aykırı yollarla

22 İmâm Ebû Yusuf, Kitabu'l-Haraç, çev. Ali Özek (İstanbul: Hisar Yayınevi, 1973), 244; Muhammed b. Ferâmuz Molla Hü̈rev, Düreru'l-hükkâm fî şerḥi gureri'l-aḥkâm (Karaçi, Mîr Muhammed Kütübhânesi, ts.), 2/64; Muhammed Selîm el-'Avvâ, fî Ușûli'n-nizâmi'l-cinâiyyi'l-İslâmî (Kâhire: Nahḍatü Mısr, 2006), 117, 124-125.

23 Uğur Alacakaptan, Suçun Unsurları (Ankara: Ankara Üniversitesi Hukuk Fakültesi Yayınları, 1975), 8.

24 Bilgi için bk. Kemal Yıldız, "Hukuka Aykırılık Kavramının Fıkıh İlmi Açısından Değerlendirilmesi”, İslam Hukuku Araştırmaları Dergisi 13 (2009), 309-311.

25 Heyet, “I'tidâ”, el-Mevsû 'atü'l-fikhiyye, (Kuveyt: Vizâratü'l-evkâf ve'ş-şüûni'l-İslâmiyye, 1406/1986), 5/202-203.

26 el-Bakara 2/190, 194, 229; el-Mâide 5/2, 87,107; et-Talâk 65/1.

27 Özkul, “Ceza Yargılamasında Hukuka Aykırı Şekilde Elde Edilen Delillerin Değerlendirilmesi Sorunu”, 401 403. 
elde edilen delillerin kullanılmasıyla ilgili “mutlak kabul yaklaşımı, belli kriterlere bağlı olarak bazı delillerin kullanılabileceği görüşü ve hukuka aykırı yollarla elde edilen delillerin kullanılmasına mutlak şekilde karşı çıkan görüşs" olmak üzere üç temel yaklaşım oluşmuştur. ${ }^{28}$

\section{1. İslâm Hukukunda İkrah ve Şiddet Sonucu Elde Edilen Delillerin İspat Değeri}

İslâm hukukunda bireylerin sözlü ve fiili tasarrufları irade, ihtiyâr ve rıza durumları dikkate alınarak değerlendirilmeye tabi tutulur. Bir irade beyanına hukuki sonuç bağlanabilmesi için öncelikle irade beyanında bulunan şahsın ehliyet sahibi olması gerekir. Buna ilaveten kişinin iç iradesi ile dışa yansıyan iradesi arasında uygunluk olmalıdır. ${ }^{29} \mathrm{Bu}$ itibarla tam eda ehliyetine sahip kimselerin baskı ve zorlama olmaksızın ortaya koydukları sözlü ve fiili tasarruflarının sorumluluğu kendilerine aittir. İrade ve rızayı kısmen ya da tamamen ortadan kaldıran veya daraltan ehliyet arızaları, kişinin hukuki/cezai sorumluluğuna da etki etmektedir. ${ }^{30}$ İkrah da bunlardan biridir. Baskı ve şiddet yoluyla kişiyi rızası dışında bir işi yapmaya ya da bir sözü söylemeye zorlamak şeklinde tanımlanan ikrahın ${ }^{31}$ cezai sorumluluğa etkisi, İslâm hukukunda çeşitli açılardan ele alınmaktadır. ${ }^{32}$ İkrah sonucu elde edilen delillerin ispat değeri de bunlardan biridir. Özellikle sanığın suç ikrarında bulunması ya da suçla ilgili maddi deliller sunması yönündeki baskılar, sorgulama ve yargılama aşamasında dikkat çekmektedir. Hatta bazı durumlarda bu baskılar, işkence boyutuna ulaşabilmektedir.

Modern hukuk sistemlerinin ve uluslararası insan hakları sözleşmelerinin insanlık suçu olarak gördüğü işkencenin ${ }^{33}$ tarihi oldukça eskiye dayanmaktadır. Avrupa'da 18. yüzyılın ortalarına kadar suçlunun cezalandırılması, ceza muhakemesinin temel amacı olarak görülmüştür. Bu sebeple olayın araştırılmasından ziyade sanığın suçlu olduğu ön kabulüyle hareket edilmiş ve bu durum ispatlanmaya çalışılmıştır. Bunun için de baskı, şiddet ve işkence

28 Şenol, Ceza Muhakemesi Hukukunda Hukuka Aykırı Delillerin Değerlendirilmesi Yasă̆ı, 69.

29 Abdülkerîm Zeydân, Niẓâmü'l-ḳaḍ̂ fi'ş-şerî 'ati'l-İslâmiyye (Beyrut: Müessesetü'r-Risâle, 1409/1989), 159-160; Ali Bardakoğlu, "İkrah", Türkiye Diyanet Vakfı İslâm Ansiklopedisi (İstanbul: TDV Yayınları, 2000), 22/32.

30 Aḥmed Fethî Behnesî, Naẓariyyetü'l-isbât fi'l-fikhi'l-cinâiyyi'l-İslâmî (Kâhire: Dârü'ş-şurûk, 1989), 170.

31 Serahsî, el-Mebsût, 24/38; Abdülkâdir 'Ûdeh, et-Teşrî 'u'l-cinâiyyi'l-İslâmî mukâranen bi'l-kânûni'l-vad'iyyi, (Beyrut: Dârü'l-Kâtibi'l-'Arabî, ts.), 2/306-307; Ayrıca bk. 'Alâuddîn 'Abdülazîz b. Aḥmed el-Buhârî, Keşfü'l-esrâr 'an ușûli Fahri'l-İslâm el-Bezdevî (Beyrut: Dârü'l-Kütübi'l-İlmiyye, 1418/1997) 4/538.

32 Kâsânî, Bedâi 'u's-sanâi 'i, 7/235; Ömer Nasuhi Bilmen, Hukuki İslâmiyye ve Istılahatı Fıkhiyye Kamusu, (İstanbul: Ravza Yayınları, 2018), 3/64, 279; Bardakoğlu, “İkrah”, 22/37.

33 Avrupa İnsan Hakları Sözleşmesi (AİHS), Madde 3; Türkiye Cumhuriyeti Anayasası (1982 Anayasası), Resmî Gazete 17863 (9 Kasim 1982) Kanun No. 2709, md. 17. 
delil elde etme yöntemleri arasında görülmüştür. ${ }^{34}$ Kur'an-1 Kerîm, hem geçmiş peygamberlerden verdiği örneklerle işkencenin tarihine 1şık tutmuş hem de bu tür eylemleri onaylamadığını ortaya koymuştur. ${ }^{35} \mathrm{Bu}$ noktada "Mü'min erkeklere ve mü'min kadınlara, yapmadıkları bir şeyden ötürü eziyet edenler, şüphesiz bir iftira ve apaçık bir günah yüklenmişlerdir" (el-Ahzâb 33/58), "Ey iman edenler! Allah için hakkı ayakta tutan, adaletle şahitlik eden kimseler olun. Bir topluma olan kininiz, sizi adaletsizliğe sürüklemesin..." (el-Mâ ide 5/8) mealindeki âyetlerin yanında Hz. Peygamber'in Cahiliye dönemi âdetlerinden burun ve kulak gibi organları kesme, gözleri oyma vb. şekillerde tezahür eden müsle uygulamasına getirmiş olduğu yasak, ${ }^{36}$ İslâm'ın ilkesel olarak işkenceye karşı olduğunu ortaya koymak için yeterlidir. Ancak Müslüman toplumlarda gerek yargılama alanında gerekse diğer alanlarda baskı ve şiddete dayalı hak ihlallerinin bütünüyle ortadan kalktığını söylemek tarihi gerçeklikle uygunluk arz etmeyecektir. Hatta muhakeme ve ceza hukuku, baskı ve şiddetin en sık gündeme geldiği alan olarak karşımıza çıkmaktadır. İşkencenin tanımlanmasında sanık ya da suçluya yapılan kötü muamelenin ön plana çıkması da buna işaret etmektedir. ${ }^{37}$

\subsection{Baskı ve Şiddet Sonucu Elde Edilen İkrarın (İtirafın) İspat Değeri}

İslâm ceza muhakemesinde sanıklar temel olarak üç kategoriye ayrılmıştır: toplum nazarında iyi haliyle tanınan, kendisine isnat edilen suçu işleme ihtimali olmayan (ya da düşük olan) kimseler, ahlaksızlığı ve haksızlığı ile tanınıp itham edilen suçu işleme ihtimali yüksek olan kimseler ve hakkında pek fazla bilgi sahibi olunmadığı için itham edilen suçu işleme ihtimali tahmin edilemeyen kimseler. ${ }^{38}$ İlk kategoride yer alan sanıklar hakkında yapılan suçlamalar, hukuken geçerli deliller olmadıkça dikkate alınmadığı gibi bunlar hakkında hapis vb. tedbir de uygulanmaz. ${ }^{39}$ Özellikle Mâlikîler bu tür kimselere mücerret ithamla suçlu muamelesi yapılmasına karşı çıkmışlardır. Ayrıca bu tutumlarıyla suçsuz

34 Şenol, Ceza Muhakemesi Hukukunda Hukuka Aykırı Delillerin Değerlendirilmesi Yasă̆ı, 8.

35 el-Bakara 2/61, 91; Âl-i İmrân 3/21, 112, 181; en-Nisâ 4/155; el-En 'âm 6/34; el-Burûc 85/4.

36 Buhârî, “ez-Zebâih ve'ș-ṣayd” 25, “Mezâlim” 30; Süleymân b. Eş'as es-Sicistânî Ebû Dâvûd, Kitâbü's-sünen, thk. Muhammed Avvâme, 2. Baskı (Beyrut: Müessesetü'r-reyyân, 2004), "Hudûd", 3.

37 Şamil Dağc1, "İşkence”, Türkiye Diyanet Vakfı İslâm Ansiklopedisi (İstanbul: TDV Yayınları, 2001), 23: 430-431.

38 İbn Kayyim, eț-Ṭuruku'l-ḥukmiyye, 265; 'Alvânî, "İslâm'da Sanık Hakları (I)", 93-94; Heyet, "Habs", elMevsî 'atü'l-fikhiyye, 16/293.

39 Ebî Muhammed Ali b. Aḥmed b. Sa îd İbn Ḥazm, el-Muhallâ, thk: Muhamamed Münîr ed-Dımeşkî (Mısır: Matba 'atü'n-Nahḍa, ts.), 8/170; Ḥasen Ebû Ḡudde, Aḥk̂̂mü's-sicn ve mu'âmeletü's-sücenâ fi'l-İslâm (Kuveyt: Mektebetü'1-Menâr, 1987/1407), 96-97; Heyet, “Ḥabs", el-Mevsû 'atü'l-fikhiyye, 16/293; Beroje, İslâm İspat Hukuku, 138. 
insanların asılsız iddialarla ve kasıtlı olarak sanık durumuna düşürülmesinin ve itibarlarının zedelenmesinin önüne geçmek istemişlerdir. ${ }^{40}$

İkinci ve üçüncü kategoride yer alan sanıklar hakkında İslâm hukukçuları daha ihtiyatlı davranmışlardır. Fakihlerin çoğunluğu, Hz. Peygamber'in ${ }^{41}$ ve ilk halifelerin

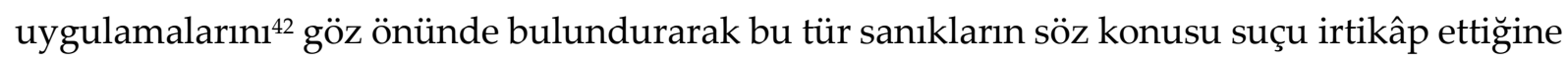
delalet eden kuvvetli karinelerin bulunması ve serbest bırakıldığında tekrar mahkemeye getirilmesinin zorluğu gibi sebeplerle alıkonulmalarının caiz olduğunu belirtmişlerdir. ${ }^{43} \mathrm{Bu}$ hapis ceza olmayıp ilgili konuda sanığı, suçluluğu ya da suçsuzluğu sabit oluncaya kadar hürriyetinden yoksun bırakmaktan ibaret bir tedbirdir. ${ }^{44} \mathrm{Bu}$ sebeple bazı fakihler, ihtiyat gereği uygulanan bu hapsin cezaya dönüşmemesi için belli bir süreyle sınırlı tutulması gerektiğini ifade etmişlerdir. İmâm Şâfiî̀nnin talebelerinden Abdullâh ez-Zübeyrî̀ye (öl.219/834) göre, sanığa isnat edilen suçun araştırılması için bir aylık süre yeterlidir. Bu sebeple ihtiyaten hapis, bir aydan fazla olmamalıdır. Şâfîi fakihlerin çoğunluğuna göre ise bu noktada karar devlet başkanı ya da onun yetkili kıldığı hâkimlerindir. ${ }^{45}$

Suçlar ve bu suçlarla ilgili delillerin toplanmasındaki süreler olayın niteliğine göre farklılık arz edeceğinden sanığın hapiste kalma süresinin hâkimin takdirine bırakılmasının uygun olacağı kanaatindeyiz. Hâkimin bu kararında sanığın sabıkasının olup olmaması ve sosyal statüsü gibi ölçütlerin yanında itham edilen suçun türü belirleyici olacaktır. Kişinin basit bir suç sebebiyle ya da mücerret suç isnadıyla özgürlüğünden alıkonmaması gerekir. ${ }^{46}$ Ancak bazı durumlarda adaletin gerçekleştirilmesi, kamu düzeninin korunması ve sanık hakkında gerekli tahkikatın yapılabilmesi için sanığın hürriyetinin kısıtlanması haklı ve zorunlu bir hal alabilmektedir. Bu noktada İslâm hukukçularının hem temel hak ve

40 Alvânî, “İslâm’da Sanık Hakları (I)”, 94; Beroje, İslâm İspat Hukuku, 139; Mücerret iddia sahiplerinin cezalandırılıp cezalandırılmayacağı hususu için bk. İbn Kayyim, eț-Ṭruku'l-ḥukmiyye, 265-266.

41 Ebû Dâvûd, "Akdiyye”, 29; Tirmizî̀, "Diyât", 20.

42 Ebü'l- 'Abbâs Ahmed b. Ebî Ahmed eț-Ṭaberî İbnü'l-Ḳâṣ, Edebü'l-Ḳậ̂h, thk. Ḥuseyn Halef el-Cebûrî (Mekke: Mektebetü'l-ḥadîk, 1409/1989), 125-127.

43 Kâsânî, Bedâi 'u's-sanâi i, 7/81; Hüsâmüddîn Ömer b. 'Abdilazîz b. Mâze el-Buhârî Ṣadrü'ş-Şehîd, Şerḥu Edebi'lKâdûi li'l-Hașșâf, thk. Yahyâ Hilâl es-Serhân (Bağdat: Mațba atü'l-İ̉şâd, 1397/1977), 2/343-344; İbn Kayyim, ețȚuruku'l-ḥukmiyye, 266-268, 273-274; Ebû Guudde, Ahkâmü̈s-sicn, 95-96; Heyet, "Habs", el-Mevsû 'atü'l-fikhiyye, (Kuveyt: Vizâratü'l-evkâf ve'ş-şüûni'l-İslâmiyye, 1409/1989), 16/292-293; Atar, İslâm Yargılama Hukukunun Esasları, 210.

44 Akman, Ceza Yargilaması, 106.

45 Mâverdî, el-Ahkâmü's-sulțâniyye, 298; Heyet, "Habs”, el-Mevsû 'atü'l-fikhiyye, 16/295.

46 Nezâr Racâ Sabtî Sabra, Aḥkâmü'l-müttehem fi'l-fiḳi'l-İslâmî (Nablus: Câmi atü'n-Necâhi'l-Vațaniyye, Külliyyetü'd-Dirâsâti'l- 'Ulyâ, Yüksek Lisans Tezi, 2006), 26-27. 
hürriyetlerin korunmasına hem de toplumsal düzenin sürekliliğine özen gösterdiklerini ifade edebiliriz. ${ }^{47}$

İslâm ceza muhakemesinde sanı̆̆ın işlemiş olduğu suçu haber vermesi ya da kendisine yöneltilen suç isnadını kabul etmesi şeklinde tanımlanan ikrar/itiraf ${ }^{48}$ ispat vasıtaları arasında ilk sırada yer alır. Ancak bu, itirafın mutlak doğru bilgi içerdiği anlamına gelmez. ${ }^{49}$ Diğer bir ifadeyle mücerret bir ikrarla sanık cezalandırıldığında hak etmediği bir ceza verilmiş olabilir. Özellikle had gerektiren bir suç işlediği yönünde itirafta bulunan sanığa müeyyide uygulamadan önce suçun unsurlarının haddi gerektirecek şekilde tamamlanmış olduğundan emin olunmalıdır. Örneğin hırsızlık suçunda had uygulanabilmesi için sanığın ceza ehliyetini haiz olmasının yanında çalınan malın muhafaza altında olması, mali bir değere sahip olması, nisap miktarına ulaşması ve gizlice alınması gibi birtakım şartlar gerekli görülmektedir. ${ }^{50} \mathrm{Bu}$ şartlardan habersiz olan sanığın itirafına dayanarak had uygulandığında adalet arayışında olan birine zulmedilmiş olacaktır. Bu sebeple hâkim, mücerret itirafla yetinmeyip suçun unsurlarının tam manasıyla oluşup oluşmadığından emin olmak için tahkikat yapmak zorundadır. ${ }^{51}$ Mevcut hukuk sistemimizde de sanığın itirafının ceza davalarında delil olarak kabul edilip edilmemesi hâkimin takdirine bırakılmıştır. Hâkim, karar vermeden önce ikrarın gerçeğe uygun olup olmadı̆̆ını araştıracak, ikrarın maddi gerçeği yansıttı̆̆ına kanaat getirdiğinde bunu dikkate alacaktır. Zira sanığın bir yakınını koruma güdüsüyle ya da ekonomik ve siyasi sebeplerle suç ikrarında bulunması ihtimal dâhilindedir. Yalan ikrar beyanlarının varlığı, ikrarın delil değerini azaltmakta ve sorgulanması ihtiyacını doğurmaktadır. ${ }^{52}$

Bir diğer ihtimal ise itirafın iradeyi sakatlayan ya da ortadan kaldıran etkenler altında yapılmış olmasıdır. Zira bir insanın kendi aleyhine itirafta bulunması sık rastlanan bir durum değildir. İslâm hukuk doktrininde gözaltında bulunan ya da ihtiyaten tutuklu yargılanan

47 Memet Zeki Uyanık, İslam Hukukunda Hapis Cezası ve Hapishane (Konya: Necmettin Erbakan Üniversitesi, Sosyal Bilimler Enstitüsü, Doktora Tezi, 2015), 63-64.

48 Farklı tanımlar için bk. Zuhaylî, Vesâilü'l-isbât, 233-235.

49 İbrâhîm Muhammed el-Harîrî, el-Kavâ 'id ve'davâbıțu'l-fiḳhiyye li nizâmi'l-ḳaḍa fi'l-ìslâm (Umman: Dârü 'Umâr, 1420/1999), 94; Ferhat Koca, "İtiraf”, Türkiye Diyanet Vakfi İslâm Ansiklopedisi (İstanbul: TDV Yayınları, 2001), 23: 461.

50 Kaḍ̂ Ebû Muhammed 'Abdulvahhâb el-Baḡdâdî el-Mâlikî, et-Telkîn fi'l-fikhi'l-Mâlikî, thk. Muhammed Sâlis Sa 'îd el-Ḡânî (Riyad: Mektebetü Nezâr Mușțafâ el-Bâz, ts), 2/507-511; İbn Rüşd el-Hafîd, Bidâyetü'l-müctehid, 814815; Kâsânî, Bedâi 'u's-sanâi 'i, 7/66 vd.

51 Beroje, İslâm İspat Hukuku, 185.

52 Adnan Deynekli, “İkrarda Manevi Unsur”, TBB Dergisi 64 (2006), 322. 
sanığa, suçunu itiraf ettirmek için baskı ve şiddet uygulamanın caizliği ve bu şekilde elde edilen itirafın ispat değeri çeşitli açlardan tartışma konusudur. Çoğunluğa göre daha önce suç işlememiş ve toplumda iyi haliyle bilinen sanı̆̆a baskı ve şiddet uygulanması caiz olmadığı

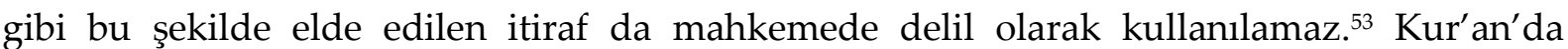
kalbinde inkâr niyeti ve isteği olmadığı halde, baskı ve şiddet sonucu inancının aksini ikrar edenin sorumlu olmadığ1 ifade edilmektedir. ${ }^{54} \mathrm{~Hz}$. Peygamber de Müslümanlardan hata, unutma ve zorlandıkları (ikrah) şeylerin sorumluluğunun kaldırıldığını bildirmiştir. ${ }^{55} \mathrm{~Hz}$. Ömer'in tavrı ise ceza muhakemesine 1şık tutar niteliktedir. Ona göre isnat edilen suçlamayı itiraf ettirmek için sanığa baskı ve şiddet uygulanması caiz olmadığı gibi ${ }^{56}$ bu şekilde kendi aleyhine ikrarda bulunan kişinin ikrarına istinaden cezalandırılması da uygun değildir. ${ }^{57} \mathrm{Bu}$ delillerden hareketle fakihlerin çoğunluğu, mükrehin hem küfrü ikrar etmesinin hem de kendi aleyhine ikrarda bulunmasının bağlayıcı olmadığı sonucuna varmışlardır. ${ }^{58}$ Diğer taraftan Nu'mân b. Beşîr'den (öl. 64/684) de çoğunluğun görüşünü destekler nitelikte bir uygulama rivayet edilmiştir. $\mathrm{O}$, hırsızlık ithamıla kendisine getirilen kişileri birkaç gün hapsetmiş, ardından yeterli delil olmadığı için sanıkları serbest bırakmıştır. Davacılar, sanıkların suçlarını itiraf ettirmek için baskı ve şiddet uygulanmadan serbest bırakılmasına karşı çıkarak Nu mân b. Beşîr'e şikâyette bulunduklarında Nu'mân; “Ne istiyorsunuz? İsterseniz onları dövdüreyim. Şayet mallarınız onlarda çıkarsa ne âlâ. Ancak mallarınız onlarda çıkmazsa size de onlara attırdığım dayağın aynısını attırırım." diyerek bunun Hz. Peygamber'in hükmü olduğunu açıklamıştır. ${ }^{59} \mathrm{Bu}$ rivayetler, meşru olan dövmenin hadler ve ta 'zîr için olduğunu, bunun da ancak suçun ispatından sonra olacağını ortaya koymaktadır. ${ }^{60}$ Mecelle de ikrârda

53 Ebû Yusuf, Kitabu'l-Haraç, 272; İbn Saîd et-Tennûhî Saḥnûn, Müdevvenetü'l-kübrâ li'l-İmâm Mâlik b. Enes, 1. Bask1 (Beyrut: Dârü'l-Kütübi'l-İlmiyye, 1415/1994), 6/293; Serahssî, el-Mebsût, 9/184-185, 24/70; Muvaffaḳuddîn Ebî Muhammed Abdullâh b. Ahmed b. Muḥammed İbn Ḳudâme, el-Kâfî, thk: Abdullâh b. Abdulmuḥsin et-Türkî (Riyad: Dârü Hicr, 1417/1997), 6/256-257; İbn Hazm, el-Muhallâ, 11/339-340; Aḥmed Fethî Behnesî, elMes'ûliyyetü'l-cinâiyye fi'l-fikhi'l-İslâmî, (Kâhire: Dârü'ş-Şurûḳ, 1409/1988), 258; Fetâva'l-hindiyye, Tashih: Abdullatîf Ḥasan Abdurrahmân, (Beyrut: Dârü'l-Kütübi'l-İlmiyye, 2000), 2/191; Sabra, Aḥkâmü'l-müttehem, 105106.

54 en-Nahl 16/106.

55 Ebû Abdillâh Muhammed b. Yezîd Mâce el-Ḳazvînî İbn Mâce, es-Sünen, thk: Beşşâr Avvâd Ma rûf, 1. Baskı (Beyrut: y.y., 1998), “Talâk” 16.

56 Sabra, Ahkâmü'l-müttehem, 111.

57 Ebû Yusuf, Kitabu'l-Haraç, 272; İbn Kudâme, el-Muğnî, 12/360; 'Ûdeh, et-Teşrî́ 'u'l-cinâiyyi'l-İslâmî, 2/311-312; Behnesî, Nazariyyetü'l-isbât, 171.

58 Ebî Bekr Muhammed b. 'Abdullâh İbnü'l-'Arabî, Aḥkâmü'l-Ḳur'ân, thk. Muhammed 'Abdulkâdir 'Ațâ (Beyrut: Dârü'l-Kütübi'l-İlmiyye, 1424/2003), 3/163; Sabra, Ahkâmü'l-müttehem, 111.

59 Ebû Dâvûd, "Hudûd", 10.

60 Behnesî, Nazariyyetü'l-isbât, 172; Sabra, Ahkâmü̈l-müttehem, 105-106. 
rıza ve ihtiyârın şart olduğunu "İkrârda mukırrın rızâsı şarttır. Binâenaleyh cebr ve ikrâh ile vâkî" olan ikrâr sahih olmaz."61 şeklinde maddeleştirmiştir.

Sanığın hırsızlık, yol kesicilik, adam öldürme vb. suçlardan sabıkalı olması ve itham edilen suçu işlemiş olabileceğine dair kuvvetli karinelerin mevcudiyeti durumunda bazı fakihler, ikrah yoluyla itirafa zorlanmasını caiz kabul etmişlerdir. ${ }^{2}{ }^{2}$ Nitekim hırsızlıkla tanınmış bir kimsenin yine aynı suçu işlediği yönünde güçlü karineler bulunmakla birlikte sanığın suçlamayı kabul etmediği durumlarda ikrarda bulunması için hapis ya da baskı araçlarının kullanılabileceği ifade edilmektedir. Kaynaklarda Hasan b. Ziyâd'a (öl. 204/819) atfedilen bu görüş, sonraki dönem bazı Hanefî hukukçular tarafından da kabul görmüştür. Fetvanın bu yönde değişmesinin gerekçesi olarak ise dönemlerinde hırsızların baskı ve zorlama olmaksızın suçlarını kabul etmemeleri gösterilmektedir. ${ }^{63}$

İbn Kayyim ise bazı Mâlikî ve Hanbelîlerin yanı sıra dönemin önde gelen fakîhlerinden de bu görüşü benimseyenlerin olduğunu ifade etmektedir. ${ }^{64}$ Bunlar görüşlerine delil olarak, verdikleri söze sadık kalmayıp ellerindeki malları gizleyen Hayberlilerin yaptıklarını ortaya çıarmak için Hz. Peygamber tarafından görevlendirilen Zübeyr b. Avvâm’ın (öl. 36/656) görev esnasında Hayberlilere ve casus olduğu değerlendirilen kimselere Hz. Peygamber'in suçu itiraf ettirmek için baskı uyguladığı yönündeki rivayetleri kullanmışlardır. ${ }^{65}$ Ayrıca bunlara göre bazı durumlarda sanı̆ga uygulanan baskı ve şiddet, hakikate ulaştıran bir araç olması yönüyle maslahat olarak görülebilmektedir. ${ }^{66}$ Ancak bu rivayetlerden biri, yapmış oldukları anlaşmaya sadık kalmayan düşmanlar; diğeri ise devletin güvenliğini tehdit eden casuslar hakkında olup suçu henüz sabit olmayan sanığın baskı ve şiddet yoluyla itirafa zorlanmasına delil teşkil edecek nitelikte olmadığı gerekçesiyle eleştiriye açıktır. ${ }^{67}$ Sanığa baskı ve şiddet uygulamakla maslahat elde edilmesine gelince, Gazzâlî’ye göre bu tür maslahat

61 Mecelle md. 1575.

62 Serahsî, el-Mebsût, 9/185; İbn Ḳayyim, eț-Ṭuruku'l-ḥukmiyye, 275; Sabra, Aḥkâmü'l-müttehem, 107.

63 Serahsî, el-Mebsût, 9/185; Muhammed Emîn İbn 'Ẩbidîn, Reddü'l-muhtâr 'ale'd-dürri'l-muhtâr şerḥu tenvîri'l-ebșâr, thk. 'Âdil Ahmed 'Abdülmevcûd- 'Ali Muhammed Muavvıḍ (Riyâd: Dârü 'Âlemi'l-Kütüb, 1423/2003), 6/144, ; Bilmen, Istılahatı Fıkhiyye Kamusu, 3/279; 'Ûdeh, et-Teşrî'u'l-cinâiyyi'l-İslâmî, 2/312-313; Behnesî, Naẓariyyetü’lisbât, 172-173.

64 İbn Kayyim, eț-Ṭuruku'l-ḥukmiyye, 275-276; Aḥmed Fethîi Behnesî, es-Siyâsetü'l-cinâiyye fi'ş-şerî'ati'lİslâmiyye (Kâhire: Dârü'ş-Şurûḳ, 1409/1988), 231.

65 İbn 'Âbidîn, Reddü'l-muhtâr, 6/146-147; Behnesî, Naẓariyyetü'l-isbât, 172; 'Umar es-Seyyid 'Umar, Hukûku'lmüttehem fi'ş-şerî'ati'l-İslâmiyye dirâse fiḳhiyye mukârane (Mekke: Câmi 'atü Ümmi'l-Kurâ, Külliyyetü'ş-Şerî'a ve'd-Dirâsâti'l-İslâmiyye, Yüksek Lisans Tezi, 1408/1988), 195.

66 Sabra, Ahkâmü'l-müttehem, 109.

67 Tâhâ C. 'Alvânî, "İslâm'da Sanık Hakları (II)", çev. F. Mehveş Kayani, İslâmî Sosyal Bilimler Dergisi 3/2 (Yaz 1415/1995), 87. 
itibar edilecek bir maslahat değildir. Zira bu maslahata karşı gelen başka bir maslahat vardır ki o da sanığın maslahatıdır. Sanığın suçlu olma ihtimali olduğu gibi suçsuz olma ihtimali de vardır. Suçsuza baskı ve şiddet uygulamaktansa, suçlunun şiddet görmemesi tercih edilir. Gazzâlî, hırsızlık gibi bir ithamla getirilen sanığa baskı ve şiddet uygulanmamasının çalınan malların geri alınmasını zorlaştıracak bir kapı aralamak olduğunu kabul etmektedir. Ancak ona göre maslahat elde etmek gayesiyle buna cevaz verildiğinde henüz suçu sabit olmamış kimselere işkence yapılmasının önü açılacaktır. ${ }^{68}$ Diğer taraftan suç objektif delillerle ispat edilmedikçe, devlet başkanı da olsa, şüphe sebebiyle kimsenin cezalandırma yetkisi olmadığını ifade eden rivayetler bulunmaktadır. İbn Abbas'tan yapılan rivayete göre Hz. Peygamber "Şayet bir kimseyi delilsiz olarak recmedecek olsaydım falanca kadını recmederdim. Zira sözleri, dış görünüşü ve yanına girip-çıkan kimseler, hakkındaki şüpheyi teyit etmektedir."69 buyurmuştur. Bu karinelere ve oluşan şüpheye rağmen Hz. Peygamber, bu kadını ne sorguya çekmiş ne de itiraf elde etmek için ona baskı uygulamıştır.

Baskı ve şiddet neticesinde elde edilen ikrarla/itirafla suçun sabit olacağını ifade edenlerin bu yaklaşımlarının daha çok kul haklarını ihlal eden cinayet ve kazf/iffete iftira gibi suçlarla ilgili olduğunu söyleyebiliriz. Zira İslâm hukuku, zina gibi birtakım suçların ifşa edilmesinden ziyade gizlenmesini istemektedir. ${ }^{70}$ Zinanın ispatı için en az dört şahidin gerekli görülmesi, ${ }^{71}$ aksi halde bunun kazf/iffete iftira kapsamında değerlendirilip müeyyideye tabi tutulacağının beyan edilmesi, ${ }^{72}$ özellikle Allah hakkını ihlal eden suçlarda hâkimin ikrardan dönmesi için kişiye telkinde bulunmasının gerekli görülmesi ${ }^{73}$ hep bu anlayışın bir neticesidir. Diğer taraftan Ebû Hanife, Ahmed b. Hanbel ve İbn Ebî Leylâ gibi fakihler, sanığın zina suçunu itiraf etmesini yeterli saymayıp bunun hâkim karşısında da dört defa ikrar edilmesini gerekli görmüşlerdir. ${ }^{74}$ Hatta Hanefîler, bu ikrarın dört farklı mecliste yapılmasını şart koşmuştur. ${ }^{75}$ İmâm Mâlik, İmâm Şâfiî ve İbn Hazm ise zina suçunun ikrarla/itirafla sabit

68 Ebû Ḥâmid Muhammed b. Muhammed Ḡazzâlî, el-Mustaṣfâ min 'ilmi'l-uṣ̂ul, thk. Hamza b. Züheyr Ḥâfız (Medine: y.y. 1413/1993), 2/490-491.

69 Müslim, "Li'ân", 12; İbn Mâce, "Hudûd", 11 (No. 2559).

70 Mevṣilî, el-İhtiyâr li ta 'lîli'l-muhtâr 2/150; el-Ḥarînî, el-Kavâ 'id ve'davâbıțu'l-fikhiyye, 97.

71 en-Nisâ $4 / 15$.

72 en-Nûr 24/4.

73 Behnesî, Nazariyyetü'l-isbât, 167.

74 Ebi'l-Ḥasan Aḥmed b. Muhammed b. Aḥmed b. Ca 'fer el-Ḳudûrî, Muhtașaru'l-Kudûrî, (Beyrut: Dârü'1-Kütübi'lİlmiyye, 1418/1997), 195; Serahsî, el-Mebsût, 9/91; Ḳâsânî, Bedâi 'u's-sanâi 'i, 7/50; İbn Ḳudâme, el-Muginî, 12/354355;

75 Serahsî, el-Mebsût, 9/91; Abdullâh b. Mahmûd b. Mevdûd Mevṣilî, el-ịhtiyâr li ta 'lîli'l-muhtâr (Beyrut: Dârü'lKütübi'l-İlmiyye, 1434/2013), 4/86-87. 
olması için sanı̆̆ın hâkim karşısında suçunu bir defa ikrar etmesini ve cezalandırılıncaya kadar bu ikrarından dönmemesini yeterli görmüşlerdir. ${ }^{76}$ Sanığın ikrardan dönmesi durumunda ise cumhura göre had cezası düşer. ${ }^{77}$

Hadlerin şüphe ile düşürülmesi noktasında en geniş davrananların Hanefiler olduğunu söyleyebiliriz. Onlara göre itiraf neticesinde zina haddi uygulanacak kişi, muhakemeden önce ya da muhakeme esnasında ikrarından dönebileceği gibi ceza infaz edilmeye başlandıktan sonra da dönebilir. Bu durumda infazın durdurulması gerekecektir. ${ }^{78}$ Buna mukabil Saê̂d b. Cübeyr (öl. 94/713?), Hasan el-Basrî (öl. 110/728), Osmân el-Bettî (öl. 143/760?), İbn Ebî Leylâ (öl. 148/765) ve Ebû Sevr (öl. 240/854) gibi fakihlerin yanı sıra Zâhirîler, hadler konusunda sanığın ikrarından dönmesine itibar edilmeyeceğini ifade ederek suçun sabit olması durumunda cezanın tatbik edilmesini gerekli görmüşlerdir.79 İbn Hazm, ikrardan dönmenin zina haddini düşüreceği yönündeki görüşün delilden yoksun olduğunu iddia etmektedir. Ona göre kişinin ikrar ettiği diğer haklardan dönmesine itibar edilmediği gibi zina ikrarından dönmesine de itibar edilmemelidir. Mâiz hadisi olarak bilinen rivayetten hareketle ikrardan dönmenin cezayı düşüreceği sonucuna ulaşmak mümkün değildir. Hz. Peygamber' in had infaz edildikten sonra "Keşke onu serbest bıraksaydınız ve bana getirseydiniz"80 şeklindeki ifadesi, ikrardan dönmeyle zina haddinin düşmesinden ziyade sanığın suçu işlediğinden emin olmak maksadıyla söylenmiştir. ${ }^{81}$

Bu noktada oluşan bir diğer görüş ise kararın hâkimin takdirine bırakılması gerektiği yönündedir. Buna göre hâkim, sanığın suçlu olduğuna kanaat getirmekle birlikte suçu ispat eden şahitlik vb. delile sahip değilse baskı ve şiddet yoluyla sanığ 1 itirafa zorlayabilir. ${ }^{82}$ Sanığın

76 Muhammed b. İdrîs eş-Şâfiî, el-Ümm, thk. Ruf'at Fevzî 'Abdülmüțțalib, (b.y.: Dârü'l-Vefâ, 1422/2001), 78/285; İbnü'l-Ḳâș, Edebü'l-Kâḍ̂̂, 485; Muhammed b. Aḥmed b. Muhammed b. Ahmed İbn Rüşd el-Hafîd, Bidâyetü'lmüctehid ve nihâyetü'l-mukteșid (Beyrut: Dârü'l-Kütübi'l-İlmiyye, 1434/2013), 806; İbn Ḥazm, el-Muhallâ, 11/176177.

77 Şâfiî, el-Ümm, 8/136; Ḳudûrî, Muhtașaru'l-Ḳudûrî, 196; Ebi'l-Ḥasen 'Ali b. Muhammed b. Habîb el-Mâverdî, elHâvi'l-Kebîr fî fikhi mezhebi'l-İmâm eş-Șâfî̀, thk. 'Ali Muhammed Muavvıḍ-'Adil 'Ahmed 'Abdülmevcûd (Beyrut: Dârü'l-Kütübi'l-İlmiyye, 1414/1994), 13/212; İbn Kudâme, el-Mug்n̂̂, 12/360; İbn Rüşd el-Hुafîd, Bidâyetü’lmüctehid, 806; İbn Ferhûn, Tabșıratü'l-hü̈kkâm, 2/57; Zuhaylî, Vesâilü'l-isbât, 761; Bek-İbrâhîm, Ṭuruku'l-isbâti'şşer 'iyye, 501; el-Harîrî, el-Kavâ 'id ve'ḍavâbıtu'l-fikhiyye, 100.

78 İmâm Ebû Yûsuf Ya'ḳûb b. İbrâhîm b. Ḥabîb b. Șa'd el-Kûfî, İhtilâfu Ebî Hanîfe ve İbn Ebî Leylâ, thk. Ebû'l-Vefâ elAfḡânî (Mısır: Maṭba'atü'l-Vefâ, 1357), 156-157; Serahsî̀, el-Mebsût, 9/94; Kâsânî, Bedâi 'u's-sanâi i, 7/232-233; Mevșilî, el-İhtiyâr li ta 'lîli'l-muhtâr 4/87-88.

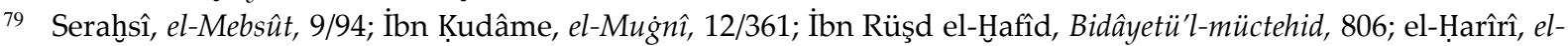
Kavâ id ve'davâbıț'l-fikhiyye, 101.

80 Tirmizî, "Hudûd", 5.

81 Değerlendirme için bk. Recep Çetintaş, İslâm Hukukunda İkrardan Dönmenin Yargısal Sonuçları (İstanbul: Asalet Yayınları, 2020), 144-148.

82 Sabra, Ahkâmü'l-müttehem, 110. 
daha önceden sabıkasının olması ya da itham edilen suçu işleyen kişilerle birlikte görülmesi, sanığa baskı uygulanmasını caiz kılan sebepler olarak görülmüşsür. ${ }^{83}$

\subsection{Baskı ve Şiddet Sonucu Elde Edilen Maddi Deliller}

İslâm muhâkeme hukukunda kavram olarak maddi delilin pek fazla kullanıldığg söylenemez. Ancak bu durum klasik dönemde maddi delilin bilinmediği anlamına gelmez. Henüz evlenmemiş ya da boşanmasının üzerinden oldukça fazla zaman geçmiş bir kadının hamile olduğunun ortaya çıkması zina suçunun ispatında; çalınan malın sanığın yanında ya da evinde bulunması hırsızlık suçunun ispatında; cinayet silahı ise kısas davalarında maddi delil olarak kullanılmaya müsaittir. ${ }^{84}$ Hamilelikte olduğu gibi bu delillerden bazısı kendiliğinden ortaya çıkarken bazıları da yetkililerin araştırma ve soruşturması neticesinde elde edilebilecek türdendir. İslâm hukukçuları bu süreçte delilin niteliğinin yanında delilin elde ediliş şekli üzerinde de durmuşlardır.

Fakihlerin genel kanaati, sanığa suçunu itiraf ettirmek için baskı ve şiddet uygulanamayacă̆ı yönündedir. Bununla birlikte özellikle hırsızlık suçlarında çalınan malın yerini ve varsa suç ortaklarını öğrenmek maksadıyla baskı yapılabileceğini kabul eden fakihler bulunmaktadır. Baskı ve şiddet sonucu sanık, suçunu itiraf edip çaldığı malı ortaya çıkarırsa suçun aslî cezası uygulanacaktır. Ancak bu ceza baskıyla elde edilen itirafa dayanmayıp hırsızlığı ortaya koyan maddi delile dayanmaktadır. ${ }^{85}$ Osmanlı kanunnamelerinde de benzer anlayışa rastlamak mümkündür:

"Ve hırsuz tâifesi işkencede ikrâr etse ikrarından gayrı alâim dahi delâlet ederse, ol ikrâr muteber ola. Hırsuzlığı zâhir olan kimesne âhar kimesne içûn şerîkimdir dese, eğer ol kimesne müttehem ve levend ise işkence edeler. Müttehem değil ise, mücerred hırsuz kavliyle işkence etmeyeler." 86

"Ve bir kimesnenin elinde veya evinde uğurluk nesne bulunsa, satun aldı ise satanı bulduralar ve bulmazsa, müttehem ise işkence edeler; meğer ki bulıcak kadıya getürüb teslim edeler veyahut yabanda bulduğun isbat ede. Ammâ işkencede ihtiyât edeler ki, kabl'es-sübût telef-i nefs olmaya. Ve eğer işkencede ölürse da vası sorulmaya." ${ }^{87}$

83 Fetâva'l-hindiyye, 2/191-192; Behnesî, Naẓariyyetü'l-isbât, 173.

84 Pekdemir, Adli Tıp ve Maddi Delil, 173-177.

85 İbn Kayyyim, eț-Ṭruku'l-ḥukmiyye, 17-18, 287; İbn Ḥazm, el-Muhallâ, 11/142; İbn 'Âbidîn, Reddü'l-muhtâr, 6/146; Sabra, Ahkâmü'l-müttehem, 116.

86 Ahmed Akgündüz, Osmanlı Kanunnâmeleri ve Hukûkî Tahlilleri (İstanbul: Osmanlı Araştırmaları Vakfı Yayınları, 1994), 7/357.

87 Ahmed Akgündüz, Osmanlı Kanunnâmeleri ve Hukûkî Tahlilleri (İstanbul: Osmanlı Araştırmaları Vakfı Yayınları, 1990), 2/43. 
“...Şer` ile sâbit olmayub bir kimesneye töhmet etseler, tehdidât ile hırsuzı bulduralar..." 88

Kanunnamelerden anlaşıldığı üzere, özellikle sanığın suçlu olabileceğine işaret eden kuvvetli harici delillerin varlığı ya da sanığın daha önceden hırsızlıkla tanınmış biri (sabıkalı) olması, itirafa zorlamak için geçerli sebep olarak görülmüştür. Ancak sanığa aslî cezanın verilebilmesi için baskı ve işkence neticesinde elde edilen mücerret itiraf yeterli olmayıp bunun maddi delillerle de desteklenmesi gerekmektedir. Bazı fakihlerin ve Osmanlı kanunnamelerinin açmış olduğu bu aralık, sonraki dönemlerde genişlemiş ve kimi zaman ilgili konuda sabıkası olmayan kişiler de haksız yere baskı ve işkenceye maruz kalmışlardır. ${ }^{89}$ Bunun farkına varan Osmanlı'da, özellikle 19. yüzyıldan itibaren, bir zihniyet değişimi olduğu gözlemlenmektedir. Çeşitli belgelerde işkenceye müsamaha edilmeyeceği açıkça ifade edilmiş, baskı ve işkence sonucu elde edilmiş itiraflar mahkeme tarafından geçersiz sayılarak suçun tespitinin ve suçluların cezalandırılmasının yasal bir zemine oturtulması anlayışı benimsenmiştir. ${ }^{90}$ Nitekim Mecelle'de cebr ve ikrah sonucu elde edilen ikrar geçersiz sayılmıştır. Ali Haydar Efendi ise maddeyi açıklama babında örnek olarak hırsızlıkla itham edilen bir kimsenin cebr ve ikrah neticesinde itirafta bulunmasının muteber olmadığını zikretmiştir. ${ }^{91}$

Ceza Muhakemeleri Usulü Kanunu'nda yasak sorgu yöntemleri "Ifade verenin ve sanı̆̆ın beyanı özgür iradesine dayanmalıdır. Bunu engelleyici nitelikte kötü davranma, işkence, zorla ilaç verme, yorma, aldatma, bedensel cebir ve şiddette bulunma, bazı araçlar uygulama gibi iradeyi bozan bedeni veya ruhi müdahaleler yapılamaz. Kanuna aykır bir menfaat vaat edilemez. Yukarıdaki fikralarda belirtilen yasak yöntemlerle elde edilen ifadeler rıza olsa dahi delil olarak değerlendirilemez." 92 şeklinde belirlenmiştir. Öğretide yasak sorgu yöntemlerinin burada ifade edilenlerle sınırlı olmadığı, aksine bunların örnek kabilinden olduğu ve sanığın iradesini özgürce kullanmasına engel olan her türlü fiilin bu yasak kapsamına gireceği kabul edilmektedir.93

\footnotetext{
Akgündüz, Osmanlı Kanunnâmeleri, 2/44.

Akman, Ceza Yargılaması, 83-84.

90 Hasan Şen, “Osmanlı'da Hapishane Mefhumu”, Osmanlı'da Asayiş, Suç ve Ceza, ed. Noếmi Levy-Alexandre Toumarkine (İstanbul: Tarih Vakfı Yurt Yayınları, ts), 206-207.

91 Ali Ḥaydar, Dürerü'l-ḥükkâm şerḥu mecelleti'l-aḥkâm, (Beyrut: Dârü 'Alemi'l-Kütüb, 1423/2003), 4/92.

92 Ceza Muhakemeleri Usulü Kanunu, Resmî Gazete 1172 (20/4/1929) Kanun No. 1412, md. 135/a

93 Şenol, Ceza Muhakemesi Hukukunda Hukuka Aykırı Delillerin Değerlendirilmesi Yasağı, 226, 288-289.
} 


\section{Sonuç}

Muhakeme hukukunda itirafın ispat vasıtaları arasında özel bir yeri vardır. Bu sebeple suçlu olduğu bilinen ya da suçlu olduğu yönünde kuvvetli şüpheler bulunan kişi ya da kişilerin ilk dönemlerden itibaren çeşitli şekillerde sorguya çekildikleri bilinmektedir. Sorgunun temel amacı, sanığa suçunu itiraf ettirmek ve suçla ilgili delilleri ortaya çıkarmaktır. Bunun için farklı sorgulama teknikleri kullanılmaktadır. İdeal olan, sorgulama sırasında sanığa baskı ve şiddet uygulanmamasıdır. İnsanlara haksız yere eziyet edilmesini yasaklayan ayetlerin yanında İslâm'ın insana vermiş olduğu değer bunu gerektirmektedir. Fakihler, toplumda iyi haliyle bilinen ve kendisine itham edilen suçu işleme ihtimali düşük olan sanıklara sorgulama sırasında baskı yapılmasına ve bunlar hakkında hapis vb. tedbirler uygulanmasına cevaz vermemişlerdir. İtham edildiği suçu işleme ihtimali bulunan ya da hakkında yeterli bilgi sahibi olunmayan sanıklara gelince fakihlerin çoğunluğu, bunların ihtiyaten belli bir süre hapsedilmeleri gerektiğini ifade etmişlerdir. Fakihlerin bu yaklaşımının isabetli olduğu ortadadır. Sanığın hapsedilmesi her ne kadar onu delilsiz olarak özgürlügünden alıkoymak gibi görünse de "Zarar-1 âmmı def' için zarar-1 hâss ihtiyâr olunur" ilkesi bazı durumlarda bunu gerekli kılmaktadır.

İtiraf elde etmek için sanı̆ga baskı ve şiddet uygulanması noktasında ise farklı görüşler olduğu görülmektedir. Genel olarak fakihler, itiraf elde etmek maksadıyla sanığa baskı ve şiddet uygulanmasına cevaz vermemişlerdir. Ancak bazı fakihler, daha önceden çeşitli suçlara karışmış, toplum nazarında kötü şöhrete sahip ve isnat edilen suçu işlemiş olduklarına dair kuvvetli karine bulunan kimselerin baskı ve şiddet yoluyla itirafa zorlanmalarını caiz görmüşlerdir. Bu kanaatte olanların temel gerekçeleri, sanıkların baskı ve şiddet olmaksızın suçu kabullenmemeleridir. Fakihlerin bu anlayışlarının, kendi dönemlerinde geçerli olan ispat yöntemleri dikkate alınarak değerlendirilmesi gerektiği kanaatindeyiz. Zira İslâm hukuku, haksız olarak bir insana eziyet edilmesine rıza göstermez. Muhtemelen bazı fakihlerin bu yönde bir kanaate sahip olmaları, özellikle kişi haklarına yönelik saldırılarda mağdurun hakkını koruma gayesine matuftur. Ancak bir tarafın hakkını koruma gayesi, diğer tarafa zulmedilmesini meşru kılmaz. Sanığın daha önce sabıkasının olması ya da suçlu kişiliği ile ön plana çıkması, isnat edilen suçu mutlak surette işlemiş olduğuna delalet etmez. Ayrıca modern muhakeme hukukunda suçludan delile ulaşma anlayışı, yerini büyük oranda delilden suçluya ulaşma anlayışına bırakmıştır. Bu sebeple baskı ve şiddet yoluyla sanığı itirafa zorlama yerine 
adli tıp ve maddi delillere dayalı objektif ispat vasıtalarından istifadeyle dava hükme bağlanabiliyorsa öncelikle bu tercih edilmelidir. Suç ispat edilemiyorsa Hz. Peygamber'in hâkimin affetmede hata etmesinin cezalandırmada hata etmesinden evlâ olduğunu ifade eden sözlerinin gereği olarak sanık serbest bırakılmalıdır. 


\section{Kaynakça}

Abdülazîz el-Buhârî, 'Alâuddîn b. Ahmed. Keşfü'l-esrâr 'an uṣûli Fahri'l-ìslâm el-Bezdevî. 4 Cilt. Beyrut: Dârü'1-Kütübi'l-İlmiyye, 1418/1997.

Akgündüz, Ahmed. Osmanlı Kanunnâmeleri ve Hukûk̂̂ Tahlilleri. 9 Cilt. İstanbul: Osmanlı Araştırmaları Vakfı Yayınları, 1990-1996.

Akman, Mehmet. Osmanlı Devleti'nde Ceza Yargılaması. İstanbul: Eren Yayıncilık, 2004.

Alacakaptan, Uğur. Suçun Unsurları. Ankara: Ankara Üniversitesi Hukuk Fakültesi Yayınları, 1975.

Ali Ḥaydar. Dürerü'l-ḥükkâm şerḥu mecelleti'l-aḥkâm. 4 Cilt. Beyrut: Dârü 'Alemi'l-Kütüb, $1423 / 2003$.

Alvânî, Tâhâ C. "İslâm'da Sanık Hakları (I)". çev. F. Mehveş Kayani. İslâmî Sosyal Bilimler Dergisi 3/1 (Bahar 1415/1995), 85-100.

Alvânî, Tâhâ C. "İslâm'da Sanık Hakları (II)". çev. F. Mehveş Kayani. İslâmî Sosyal Bilimler Dergisi 3/2 (Yaz 1416/1995), 81-94.

Aslan, Nasi. "Kur'ân ve Sünnete Göre Sanık ve Mahkûm Hakları". Kur'ân ve Sünnete Göre Temel İnsan Hakları. ed. Muhsin Demirci. 531-565. İstanbul: Ensar Neşriyat, 2014.

Atar, Fahrettin. İslâm Yargılama Hukukunun Esasları. İstanbul: Marmara Üniversitesi İlahiyat Fakültesi Vakfı Yayınları, 2. Basım, 2017.

Avvâ, Muhammed Selîm. fî̀ Ușûli'n-niẓ̂mi'l-cinâiyyi'l-İslâmî. Kâhire: Nahḍatü Misr, 2006.

Bardakoğlu, Ali. "İsbat". Türkiye Diyanet Vakfı İslâm Ansiklopedisi. 22: 492-495. İstanbul: TDV Yayınları, 2000.

Bayındır, Abdulaziz. İslâm Muhâkeme Hukûku. İstanbul: Süleymaniye Vakfı Yayınları, 2. Basım, $1437 / 2015$.

Behnesî, Aḥmed Fethî. Naẓariyyetü'l-isbât fi'l-fikhi'l-cinâiyyi'l-İslâmî. Kâhire: Dârü'ş-Şurûk, 5. Basım, 1410/1989.

Behnesî, Ahmed Fethîi. el-Mes'ûliyyetü'l-cinâiyye fi'l-fikhi'l-İslâmî. Kâhire: Dârü'ş-Şurûk, 4. Basım, 1409/1988.

Behnesî, Aḥmed Fethî. es-Siyâsetü'l-cinâiyye fi'ş-şerî'ati'l-İslâmiyye. Kâhire: Dârü'ş-Şurûk, 2. Basım, 1409/1988.

Bek, Aḥmed İbrâhîm- İbrâhîm, Vâṣ̂l 'Alâuddîn Aḥmed. Turuku'l-isbâti'ş-şer 'iyye. Kahire: Mektebetü'l-Ezheriyye li't-Türâs, 4. Basım, 2003.

Beroje, Sahip. Ceza Muhâkemesi Hukuku Açısından İslâm İspat Hukuku. Ankara: Fecr Yayınları, 2007.

Beyḥakî, Ebî Bekr Ahmed b. Ḥuseyn b. Alî. es-Sünenü'l-kübrâ. thk. Muhammed Abdülkâair Ațâ. 11 Cilt. Beyrut: Dârü'l-Kütübi'l-'Illmiyye, 3. Basım, 1424/2003.

Bilmen, Ömer Nasuhi. Hukuki İslâmiyye ve Istılahatı Fıkhiyye Kamusu. 8 Cilt. İstanbul: Ravza Yayınları, 2. Basım, 2018.

Buhârî, Ebû Abdillah Muhammed b. İsmâ' îl. el-Câmi 'u's-șahîh. 8 Cilt. İstanbul: Çağrı Yayınları, 2. Basim, 1992.

Ceza Muhakemeleri Usulü Kanunu. Resmî Gazete 1172 (20/4/1929) Kanun No. 1412.

Çetintaş, Recep. İslâm Hukukunda İkrardan Dönmenin Yargıısal Sonuçları. İstanbul: Asalet Yayınları, 2. Basim, 2020.

Dağcl, Şamil. "İşkence”. Türkiye Diyanet Vakfı İslâm Ansiklopedisi. 23/429-433. İstanbul: TDV Yayınları, 2001.

Deynekli, Adnan. “İkrarda Manevi Unsur”. TBB Dergisi 64 (2006), 321-336. 
Ebû Dâvûd, Süleymân b. Eş'as es-Sicistânî. Kitâbü's-sünen. 4 Cilt. thk. Muhammed Avvâme. Beyrut: Müessesetü'r-Reyyân, 2. Basım, 2004.

Ebû Guudde, Ḥasen. Ahkâmü's-sicn ve mu'âmeletü's-sücenâ fi'l-İslâm. Kuveyt: Mektebetü'lMenâr, 1987/1407.

Ebû Yusuf, İmâm. Kitabu'l-Haraç. çev. Ali Özek. İstanbul: Hisar Yayınevi, 2. Basım, 1973.

Ebû Yûsuf, Ya'ḳûb b. İbrâhîm b. Habîb b. Șa'd el-Ḳ̂fî̀, İhtilâfu Ebî Hanîfe ve İbn Ebî Leylâ. thk. Ebû'l-Vefâ el-Afḡânî. Misır: Maṭba'atü'l-Vefâ, 1357/1938.

Ebû Zehrâ, Muhammed. el-Cerîme ve'l- 'ukûube fi'l-fikhi'l-İslâmî, (el-'Ukûbe). Kahire: Dârü'lFikri'l-'Arabî, ts.

Erturhan, Sabri. "Kişisel Boyutlu Suçların Gizlenmesinin İslâm Ceza Hukuku Açısından Değerlendirilmesi". Cumhuriyet Üniversitesi İlâhiyat Fakültesi Dergisi 5/2 (2001), 259-291.

Fetâva'l-Hindiyye. Tashih: Abdullatîf Hasan Abdurrahmân. 6 Cilt. Beyrut: Dârü'l-Kütübi'lİlmiyye, 2000.

Ḡazzâlî, Ebû Ḥâmid Muhammed b. Muhammed. el-Mustașfâ min 'ilmi'l-uṣ̂ul. thk. Hamza b. Züheyr Hâfız. 4 Cilt. Medine: y.y. 1413/1993.

Harîrî, İbrâhîm Muhammed. el-Kavâ id ve'davâbıțu'l-fikhiyye li niẓ̂ami'l-ḳadâ fi'l-ìslâm. Umman: Dârü 'Umâr, 1420/1999.

Heyet. "I'tidâ". el-Mevsû'atü'l-fikhiyye. 2/202-203. Kuveyt: Vizâratü'l-evkâf ve'ş-şüûni'lİslâmiyye, 2. Basım, 1406/1986.

Heyet. "Habs". el-Mevsû 'atü'l-fikhiyye. 16/282-330. Kuveyt: Vizâratü'l-evkâf ve'ş-şüûni'lİslâmiyye, 2. Basım, 1409/1989.

İbn 'Âbidîn, Muhammed Emîn. Reddü'l-muhtâr 'ale'd-dürri'l-muhtâr şerhu tenvîri'l-ebșâr. thk. 'Âdil Ahmed 'Abdülmevcûd-'Ali Muhammed Muavvıḍ. 10 Cilt. Riyâd: Dârü Âlemi'lKütüb, 1423/2003.

İbnü'l-'Arabî, Ebî Bekr Muhammed b. 'Abdullâh. Ahkâmü'l-Kưr'ân. thk. Muhammed 'Abdulḳâdir 'Ațâ. 4 Cilt. Beyrut: Dârü'l-Kütübi'l-İlmiyye, 3. Basım, 1424/2003.

İbn Ferhûn, Burhânüddîn Ebi'l-Vefâ İbrâhîm b. Şemsüddîn Ebî 'Abdillâh Muhammed. Ṭabșıratü'l-hü̈kkâm fì uṣ̂lli'l-akdịe ve menâhici'l-Ahkâm. 2 Cilt. Riyad: Dârü 'Alemi'lKütüb, 1423/2003.

İbn Ḥazm, Ebî Muhammed Ali b. Aḥmed b. Sa î̀d. el-Muḥallâ. thk. Muhammed Münîr edDimeşkî. 11 Cilt. Misır: Matba 'atü'n-Nahḍa, ts.

İbn Mâce, Ebû Abdillâh Muhammed b. Yezîd Mâce el-Ḳazvînî. es-Sünen. Thk. Beşşâr Avvâd Ma rûf. 6 Cilt. Beyrut: y.y., 1998.

İbnü'l-Kâș, Ebü'l- 'Abbâs Aḥmed b. Ebî Ahmed eț-Ṭaberî. Edebü'l-Ḳ̂ḍ̣̂. thk. Ḥuseyn Halef elCebûrî. 2 Cilt. Mekke: Mektebetü'l-ḥadîk, 1409/1989.

İbn Kayyim el-Cevziyye, İmâm Ebî 'Abdillâh Muhammed b. Ebî Bekr b. Eyyûb. eț-Turuku'lhukmiyye fi's-siyâseti'ş-şer'iyye. thk. Nâyif b. Aḥmed el-Ḥamed. Mekke: Dârü 'Alemi'lFevâid, 1428/2007.

İbn Ḳudâme, Muvaffaḳuddîn Ebî Muḥammed Abdullâh b. Ahmed b. Muḥammed. el-Muğnî. thk. Abdullâh b. Abdulmuḥsin et-Türkî. 15 Cilt. Riyâd: Dârü 'Alemi'l-Kütüb, 3. Basım, 1417/1997.

İbn Kudâme, Muvaffaḳuddîn Ebî Muhammed Abdullâh b. Ahmed b. Muhammed. el-Kââì. thk. Abdullâh b. Abdulmuhsin et-Türkî. 6 Cilt. Riyad: Dârü Hicr, 1417/1997.

İbn Rüşd el-Hुafîd, Muhammed b. Aḥmed b. Muhammed b. Aḥmed. Bidâyetü'l-müctehid ve nihâyetü'l-mukteșid. Beyrut: Dârü'l-Kütübi'l-İlmiyye, 5. Basım, 1434/2013.

İbn Teymiyye, Şeyhü̈l-İslâm Takiyyüddîn Aḥmed b. 'Abdi'l-Ḥalîm. es-Siyâsetü'ş-şer'iyye. Riyad: Vizâratü'ş-Şuûni'l-İslâmiyye, 1419/1999. 
Kaḍ̂i 'Abdulvahhâb, Ebû Muhammed 'Abdulvahhâb el-Bağdâdî el-Mâlikî. et-Telkîn fi'l-fikhi'lMâlikî̀. thk. Muhammed Sâlis Sa îd el-Ḡânî. Riyad: Mektebetü Nezâr Muștafâ el-Bâz, ts.

Ķaradâĝ̀, 'Ârif 'Ali 'Ârif el-. Mesâilü fikhiyye mu'âṣıra. Malezya: IIUM Press-International Islamic University Malaysia, 1432/2011.

Kâsânî, İmâm 'Alâuddîn Ebî Bekr b. Mes 'ûd. Kitâbü bedâi 'u's- sanâi 'i fî̀ tertîbî'ş-şerâi i 7 Cilt. Beyrut: Dârü'l-Kütübi'l-'Arabî, 2. Basım, 1394/1974.

Koca, Ferhat. "İtiraf". Türkiye Diyanet Vakfı İslâm Ansiklopedisi. 23/461-462. İstanbul: TDV Yayınları, 2001.

Koşum, Adnan. İslam Hukuk Doktrininde Yargı Hataları. Isparta: Fakülte Kitabevi, 2004.

Kudûrî, Ebi'l-Ḥasan Aḥmed b. Muhammed b. Aḥmed b. Ca fer. Muhtașaru'l-Ḳudûrî. Beyrut: Dârü'l-Kütübi'l-i̇lmiyye, 1997.

Mâverdî, Ebi'l-Ḥasen 'Ali b. Muhammed b. Ḥabîb. el-Ahkâmü's-sulțâniyye ve'l-velâyâti'd-dîniyye. thk. Kâḍ̂i Nebîl 'Abdurrahmân Hayyââi. Beyrut: Dârü'l-Erḳâm, ts.

Mâverdî, Ebi'l-Ḥasen 'Ali b. Muḥammed b. Ḥabîb. el-Hâvi'l-Kebîr fî fiḳhi mezhhebi'l-İmâm eş-Şâfî̀. thk. 'Ali Muhammed Muavvıḍ-'Adil 'Aḥmed 'Abdülmevcûd. 18 Cilt. Beyrut: Dârü'1Kütübi'l-İlmiyye, 1414/1994.

Mevṣ1lî, Abdullâh b. Mahmûd b. Mevdûd. el-İhtiyâr li ta 'tîli'l-muhtâr. 5 Cilt. Beyrut: Dârü'lKütübi'l-i̇lmiyye, 5. Basım, 1434/2013.

Molla Hü̈rev, Muhammed b. Ferâmuz. Düreru'l-hüukkâm fî şerḥi ḡureri'l-aḥkâm. Karaçi, Mîr Muhammed Kütübhânesi, ts.

Özkül, Fatih, "Ceza Yargılamasında Hukuka Aykırı Şekilde Elde Edilen Delillerin Değerlendirilmesi Sorunu". Uyuşmazlık Mahkemesi Dergisi 9 (Haziran 2017), 397-425.

Pekdemir, Şevket. İslam Ceza Hukukuna Göre Adli Tıp ve Maddi Delil. Ankara: Nobel Bilimsel Eserler, 2018.

Sabra, Nezâr Racâ Sabtî. Ahkâmü'l-müttehem fi'l-fikhi'l-i̇slâmî. Nablus: Câmi'atü'n-Necâhi'lVațaniyye, Külliyyetü'd-Dirâsâti'l-'Ulyâ, Yüksek Lisans Tezi, 2006.

Ṣadrü'ş-Şehîd, Hüsâmüddîn Ömer b. 'Abdilazîz b. Mâze el-Buhârî. Şerḥu Edebi'l-Kâdû li'lHașșâf. thk. Yahyâ Hilâl es-Serhân. 4 Cilt. Bağdat: Mațba atü'l-İrşâd, 1397/1977.

Sahnûn, İbn Saîd et-Tennûhî. Müdevvenetü'l-kübrâ li'l-İmâm Mâlik b. Enes. 4 Cilt. Beyrut: Dârü'lKütübi'l-İlmiyye, 1415/1994.

Serahsî, Şemsü'l-Eimme Ebû Bekr Muhammed b. Ebî Sehl. el-Mebsût. 31 Cilt. Beyrût: Dârü’lMârife, 1989.

Şâfiî, Muhammed b. İdrîs. el-Ümm. thk. Rıf'at Fevzî 'Abdülmütțalib. 11 Cilt. b.y.: Dârü'1-Vefâ, $1422 / 2001$.

Şen, Hasan. “Osmanlı'da Hapishane Mefhumu”. Osmanlı'da Asayiş, Suç ve Ceza. ed. Noếmi Levy-Alexandre Toumarkine. 200-211. İstanbul: Tarih Vakf1 Yurt Yayınları, ts.

Şenol, Cem. Ceza Muhakemesi Hukukunda Hukuka Aykırı Delillerin Değerlendirilmesi Yasă̆ı. İstanbul: Marmara Üniversitesi, Sosyal Bilimler Enstitüsü, Doktora Tezi, 2015.

Tirmizî, Ebû 'Îsâ Muhammed b. 'Îsâ b. Sevre. el-Câmi 'u'ṣ- șahîh. 5 Cilt. Beyrut: Dârü'l-Ḡarbi'lİslâmî, 2. Basım, 1998.

'Ûdeh, 'Abdülkââdir. et-Teşrî'u'l-cinâiyyi'l-İslâmî mukâranen bi'l-kânûni'l-vaḍiyyi. 2 Cilt. Beyrut: Dârü'l-Kâtibi'l-'Arabî, ts.

'Umar, es-Seyyid 'Umar. Hukûkuku'l-müttehem fi'ş-şerî'ati'l-İslâmiyye dirâse fiḳhiyye mukârane. Mekke: Câmi 'atü Ümmi'l-Ḳurâ, Külliyyetü'ş-Şerî'a ve'd-Dirâsâti'l-İslâmiyye, Yüksek Lisans Tezi, 1408/1988.

Uyanı,, Memet Zeki. İslam Hukukunda Hapis Cezası ve Hapishane. Konya: Necmettin Erbakan Üniversitesi, Sosyal Bilimler Enstitüsü, Doktora Tezi, 2015. 
Yıldız, Kemal. İslâm Yargılama Hukukunda Şahitlik. İstanbul: Hâcegân Akademi Kitaplığı, 2005.

Yıldız, Kemal. “Hukuka Aykırılık Kavramının Fıkıh İlmi Açısından Değerlendirilmesi”. İslam Hukuku Araştırmaları Dergisi 13 (2009), 305-312.

Zâhịm, Muḥammed b. 'Abdullâh. Âsâru tațbîki'ş-Şerî'ati'l-İslâmiyye fì men 'i'l-cerîme. Kahire: Dârü'l-Menâr, 2. Basım, 1412/1992.

Zehrânî, Saî̂d b. Dervîş. Tarâiku'l-ḥukm fi'ş-şerî'ati'l-İslâmiyye. Cidde: Mektebetü'ṣ-Ṣahâbe, $1414 / 1994$.

Zeydân, 'Abdülkerîm. Niẓ̂amü'l-ḳaḍâ fi'ş-şerî'ati'l-İslâmiyye. Beyrut: Müessesetü'r-Risâle, 2. Basım, 1409/1989.

Zuhaylî, Vehbe. Vesâilüll-isbât fi'ş-şerî'ati'l-İslâmiyye fi'l-muâmelâti'l-medeniyye ve'l-ahvâli'şşahșiyye. 2 Cilt. Şam-Beyrut: Mektebetü Dâri'l-Beyân, 1402/1982.

1982 Anayasası, Türkiye Cumhuriyeti Anayasası. Resmî Gazete (2709. 17863) (9 Kasım 1982). Erişim 10 Eylül 2020. https://www.mevzuat.gov.tr/MevzuatMetin/1.5.2709.pdf 